\title{
Alteration of Liver Function in Preeclampsia and Eclampsia
}

\author{
Dilip Kumar Bhowmik \\ Rafia Akhtari' \\ Sadhu Uttam Kumar ${ }^{2}$ \\ Madhusudan Saha ${ }^{3}$ \\ Dipal Krishna Adhikary ${ }^{4}$
}

'Dept of Obstetrics \& Gynaecology

Sylhet M A G Osmani Medical College Sylhet, Bangladesh.

${ }^{2}$ Dept of Medicine

Sylhet M A G Osmani Medical College

Sylhet, Bangladesh.

${ }^{3}$ Department of Gastroenterology

North East Medical College

Sylhet, Bangladesh.

${ }^{4}$ Department of Cardiology

Bangabandhu Sheikh Mujib Medical University Shahbag, Dhaka, Bangladesh.
${ }^{*}$ Correspondence to:

\section{Dr. Dilip Kumar Bhowmik}

Associate Professor

Department of Obstetrics \& Gynaecology

Sylhet M A G Osmani Medical College

Sylhet, Bangladesh.

Cell: +88-01711349775

E-mail: dbhowmiksomc@gmail.com

\begin{abstract}
Introduction: Abnormal liver function in patients with PET and eclampsia affect both maternal and fetal outcome negatively. This study was done to see change of liver function in comparison to normal pregnancy and normal reference value. Methods: Consecutive 47 patients of PET and eclampsia were taken as cases and 35 normal expectant mother were enrolled as controls. ALT, AST, alkaline phosphatase, serum bilirubin, serum creatinine and urine for albumin of patients andnormal pregnant women were tested and compared. Results: ALT, AST, S. Bilirubin, Alkaline phoshatase levels were elevated with more proteinuria among patients with PET and eclampsia, but ALT and alkaline phosphatase levels and level of proteinuria were significantly higher. Conclusions: Liver function impairment is very common in pre-eclampsia and eclampsia.
\end{abstract}

Key words: PET; Eclampsia; Liver function.

\section{INTRODUCTION}

Preeclampsia (PET) and eclampsia are pregnancy induced hypertensive disease. PET is diagnosed clinically with presence of hypertension, oedema and proteinuria in absence of preexisting hypertension and renal disease. In addition to these convulsion is present in eclampsia ${ }^{1}$. These are pregnancy specific hypertensive syndrome, when severe, can cause substantial maternal and fetal mortality and morbidity ${ }^{2}$. Prevalence of abnormal liver function tests in pregnancy complicated by PET and eclampsia varies from $20-30 \%$.

Pathophysiology of PET and eclampsia is not clearly known. Maternal endothelial dysfunction mediated by excess placenta-derived soluble VEGF receptor 1 is emerging as prominent component in disease pathogenesis ${ }^{5}$. Preclampsia and eclampsia occur during second and third trimester of pregnancy ${ }^{6}$. It affects function of various organs and their metabolism. Hepatic damage is seen in severe preeclamsia and eclampsia ${ }^{7}$.

With this background this study was designed to see the change of liver function in PET and eclampsia in relation to normal pregnancy and normal reference value.

\section{MATERIALS AND METHODS}

This prospective cross sectional study was conducted in the Department of Gynaecology and Obstetrics, Sylhet MA G Osmani Medical College Hospital, Sylhet from January 2012 to November 2012. Consecutive patients with preeclamsia and eclampsia admitted under the department were enrolled in these study. Thirty five women of uncomplicted pregnancy were also taken as control. Women having multiple pregnancy, gestational diabetes, obesity, past history of hypertension, diabetes, renal disease, liver disease, and unwilling to take part in the study were excluded from the study.

Complete history, physical examination findings were noted. Blood samples were collected from patients and controls. Estimatiotion of levels of serum bilirubin, ALT, AST, Alkaline phosphatase, serum creatinine were performed by enzymatic assay. Urinary protein was aslo seen by heat coagulation test. The result was analysed using SPSS 12 version. Mann-whitney test was done to see significance of difference and $\mathrm{P}$ value $<0.05$ was taken as significant. 


\section{RESULTS}

Consecutive 27 patients with PET and 20 patients with eclampsia were taken as cases and 35 expecting mothers with uncomplicated pregnancy were taken as controls. Age of patients varied from 26 years to 40 years (mean 33.7 years) and that of control varied from 20-35 years (mean 28.03 years). All of the cases and controls had pregnancy of either second or third trimester with mean duration of amenorrhoea 34.7 weeks and 35.51 weeks respectively (Table 1 ).

Table 1 : Profile of patients and controls

$\begin{array}{lllll}\text { Patients } & \begin{array}{l}\text { Controls } \\ \text { Range }\end{array} & \text { Mean } & \text { Range } & \text { M ean } \\ \text { A ge } & 26-40 & 33.7 & 20-35 & 28.03 \\ \text { Gravida } & 1-6 & 2.1 & 1-5 & 2.6 \\ \text { Duration } & 26-40 & 34.7 & 30-39 & 34 . .51 \\ \text { amenorrhoea } & & & & \end{array}$

Table 2 : Comparison of Blood pressure and LFT between patients and controls

\begin{tabular}{|c|c|c|c|c|c|c|}
\hline & $\begin{array}{l}\text { Patients } \\
\mathrm{N}=47 \\
\text { Range }\end{array}$ & $\begin{array}{l}\text { Normal } \\
\text { value } \\
\text { Mean }\end{array}$ & $\begin{array}{l}\text { Control } \\
N=35 \\
\text { Range }\end{array}$ & Range & Mean & P value \\
\hline $\begin{array}{l}\text { BP systolic } \\
\text { BPdiastolic } \\
\text { ALT u/l } \\
\text { AST u/l } \\
\text { Bilirubin mg/dl } \\
\text { alkalinephosphatase } \\
\text { Serum creatinin } \\
\text { Proteinuria } \\
\text { present (N) }\end{array}$ & $\begin{array}{l}120-240 \\
90-140 \\
19-821 \\
18-630 \\
0.65-2.5 \\
140-455 \\
.62-3.1 \\
47\end{array}$ & $\begin{array}{l}172.55 \\
110.88 \\
75.22 \\
60.3 \\
.93 \\
251.35 \\
92 \\
\text { Absent }\end{array}$ & $\begin{array}{l}\text { Up to } 40 \\
\text { Up to } 40 \\
\text { Up to } 1.0 \\
\text { Up to } 250 \\
\text { Up to } 1.2 \\
3\end{array}$ & $\begin{array}{l}90-130 \\
60-85 \\
28-40 \\
24-49 \\
0.6-1.3 \\
120-367 \\
0.7-2.8 \\
0.00\end{array}$ & $\begin{array}{l}116.42 \\
74.12 \\
32.6 \\
33.54 \\
0.86 \\
159 \\
1.03\end{array}$ & $\begin{array}{l}0.00 \\
0.00 \\
0.00 \\
0.251 \\
0.703 \\
0.00 \\
0.00\end{array}$ \\
\hline
\end{tabular}

Table 3 : N umber of samples having abnormal liver and renal function

\begin{tabular}{llll} 
& $\begin{array}{l}\text { normal reference } \\
\text { value }\end{array}$ & $\begin{array}{l}\text { raised } \\
\text { (patients) }\end{array}$ & $\begin{array}{l}\text { Raised } \\
\text { (controls) }\end{array}$ \\
ALT & Up to $40 \mathrm{u} / \mathrm{L}$ & $23(48.93 \%)$ & none \\
AST & Up to $40 \mathrm{u} / \mathrm{L}$ & $15(31.91 \%)$ & $4(11 \%)$ \\
$\begin{array}{l}\text { Alkaline } \\
\text { phosphatase }\end{array}$ & up to $250 \mathrm{u} / \mathrm{L}$ & $12(25.53 \%)$ & $1(2.9 \%)$ \\
$\begin{array}{l}\text { Creatinine } \\
\text { S. Bilirubin }\end{array}$ & $0.6-1.2 \mathrm{mg} / \mathrm{dl}$ & $6(12.7 \%)$ & $3(8.6 \%)$ \\
\hline
\end{tabular}

ALT level was normal in all controls according to normal reference range, while it was raised among $23(48.93 \%)$ patients and difference was significant $(P=0.00)$. A ST level was elevated among $4(11 \%)$ controls and 15 patients (31.91\%). S. bilirubin level was mildly elevated among 06 patients and 04 controls without significant difference. ALP level was raised among 1 control and 12 patients where difference was significant $(P=0.00)$. Serum creatinine level was elevated in three controls and 06 patients.

\section{DISCUSSION}

Many publications on specific causes of abnormal LFT established by problem guided investigations are available ${ }^{8,9}$. But epidemiology of most pregnancy related liver disorder is either unknown or partially recorded ${ }^{8}$. PET and eclampsia are pregnancy related complications with mortality rate less thean $1 \%{ }^{8}$. And abormal liver function occurs in $20-30 \%$ of pregnancies complicated by PET and eclampsia, ${ }^{3,4}$ and are associated with poor maternal and fetal outcome ${ }^{3}$.

In our study ALT, AST, bilirubin and alkaline phosphatase were elevated in 23(48.93\%), $15(31.91 \%), 6(12.7 \%)$ and 12 $(25.53 \%)$ patients respectively which are consistent with other studies. Mechanism of raised liver enzymes is hypervascularisation and vasoconstriction of liver leading to cell injury, alteration of membrane permeability and damage to hepatocytes ${ }^{9.10}$. In our study levels of ALT, A Ikaline phosphatase are significantly higher in PET and eclampsia in comparison to those of normal pregnant mother and normal reference level.

Women with PET and eclampsia with abnormal liver function have chance of greater proteinuria and more maternal complications than those with normal liver function ${ }^{10}$. In our study proteinuria among patients with PET and eclampsia were significantly higher which is consistent with other studies. B ut in our study outcome of pregnancy both fetal and maternal outcome were not seen. Further well designed study to see outcome of pregnancy among PET and eclampsia patients with abnormal liver function may be done. Information about abnormal liver function in patients with PETR and eclampsia may allow appropriate obstetric planning including delivery timing.

\section{CONCLUSION}

PET and eclampsia are pregnancy related hypertensive disorder those may lead to abnormal liver function. So prior information of liver function in such patients may help in planning proper intervention to improve both maternal and fetal outcome.

\section{REFERENCES}

1. Campbell S, Lees C. Obstetric emergencies, in Campbell S, Lees C. Obstetrics by Ten Teachers, 17 th Edition, L ondon, B ook Power 2000; pp 3003-3017

2. Venkatesh S, Toporsian M, A ntioxidant study in preeclampsia. International J ournal of Gynaecology and obstetric 2006; 3(2) : 241 -43

3. B orglin NE. Serum transaminase activity in uncomplicated and complicated pregnancy and in new born. J. Clin Endocrin M etab 1958; 18:872-77

4. Romero R, Vizoso J, Emamian $M$ et al. Clinical significance of liver dysfunction in pregnancy induced hypertension. A $\mathrm{m}$ J Perinatol 1988; 5: 146-51

5. M agnussen EB, Vatten LJ. Pregnancy cardiovascular risk factor as predictor of preeclampsia. J M ed 2007; 14:335-39

6. M ehta V, Chakraborty AS. A utonomic functions during different phase of menstrual cycle. Indian J Physiol Pharmacol 1993; $37: 56$ - 58.

7. Burroughs' A K, Heathcote EJ. The Liver in Pregnancy. In Dooley J S, Lok A S F, Burroughs' AK, Heathcote EJ, Sherlock's Disease of The Liver and Biliary System, 12 th edition, UK, Wiley-Blackwell 2011; pp 602-14

8. K nox TA, Olans LB. Liver disease in pregnancy. New Engl J M ed 1996; 335:569-76

9. Castro M A, Fassett MJ, Reynolds TB, Shaw KJ, Goodwin TM. Reversible peripartum liver failure: a new perspective on diagnosis, treatment and cause of acute fatty liver of pregnancy, based on 28 consecutive cases. A m J Obstet Gyanaecol 1999; 181: 389-95

10. Girling JC, Dow E, Smith JH. Liver function test in preeclampsia: importance of comparisopn with reference range derived from normal pregnancy. B ritish J Obstet and Gynaecol 1997; 104: 246-50. 